\author{
Ryazanova E.V. \\ Morel Morel D.A.
}

\section{«HAZARDOUS ZONES» WITHIN «SECURITY PERIMETER»: COMPARATIVE STUDY ON THE MATERIAL OF FOLKLORIC DISCOURSE}

1) $\mathrm{PhD}$ in Philology, associate professor. Department of foreign languages

Saint Petersburg National Research University of Information Technologies, Mechanics and Optics, 49 Kronverksky Avenue, Saint Petersburg, 197101, Russia. E-mail: e.v.ryazanova@mail.ru

2) $\mathrm{PhD}$ in Philology, associate professor. Department of foreign languages and professional communication Belgorod National Research University. 85 Pobeda St., Belgorod, 308015, Russia

E-mail:morel@bsu.edu.ru

\begin{abstract}
The article considers the concept of "house" as a core element of "security perimeter" (the term by A. Leroy-Gourhan) on the material of English, Russian and Scottish ballads. Two models of "house" were built, revealing national specificity but, however, remarkable similarities. The main grounds on which these models differ are the overall degree of openness / closure towards the outside world, the clarity of boundaries between loci, the degree of privacy of the inner loci, the extent of the mediator space. It is shown that in both cases the house is perceived as a highly complicated structure, an open system which internal and external borders are completely or partially pervious in some segments. It causes some vulnerabilities to negative external impacts (of social and supernatural origin) in "security perimeter" and loci of "space under threat" inside the house (and the adjoining protected areas). In addition, it is shown that the "security perimeter" as a complex hierarchical system displays the properties of self-similarity.
\end{abstract}

Key words: security perimeter; ballad; locus; boundary; hazard; house.

Рязанова E.B., Морель Морель Д.А.

\section{«ЗОНЫ РИСКА» ВНУТРИ «ПЕРИМЕТРА БЕЗОПАСНОСТИ»: СОПОСТАВИТЕЛЬНОЕ ИССЛЕДОВАНИЕ НА МАТЕРИАЛЕ ФОЛЬКЛОРНОГО ДИСКУРСА}

The term «security perimeter», proposed by the prominent French anthropologist and archeologist Andre Leroi-Gourhan in his work «Le geste et la parole», possesses, from our point of view, high heuristic and integrative potential which has not been completely revealed by modern science. The demand for it at the present stage of development of scientific thought and society in general seems to be obvious and is bound to the study and solution of a wide spectrum of the problems (security in its multifarious aspects, opposition «friend-or-foe», alienation, shortening personal space, etc.).

According to A. Leroi-Gourhan, human sense of security is based on placing an individual into a shelter, under cover and bringing him into homelike, group space and time (to be more precise, biological and social rhythms) [9, p. 139-140]. At the same time, a basis, «bridge-head» for domestication of space-time and the center of already «human» space-time, symbolically separated from the chaos of the external world, is a dwelling (and, in the broad sense, settlement) [ibid, p. 149-154]).

Taking into consideration the thesis by A. Leroi-Gourhan about a concentric character of the picture of the world of the settled people [ibid, p. 155-163], the data about organization of the world model divided by concentric boundaries of the growing radius being inherent in mythological consciousness of the Slavs [1, p. 28; 2, p. 23], the modern conceptions of organization of the category «space», topos and locos[4] and concentricity of «personal space» [7], we have proposed our interpretation of «security perimeter». It implies the presentation of the latter in the form of the system of concentric rings of the boundaries dividing social and psychological space into the zones with decreasing (as the remoteness from «I $\gg$-center increases) degree of development and, consequently, the security (real or presumed) and psychological comfort (Fig. 1). 


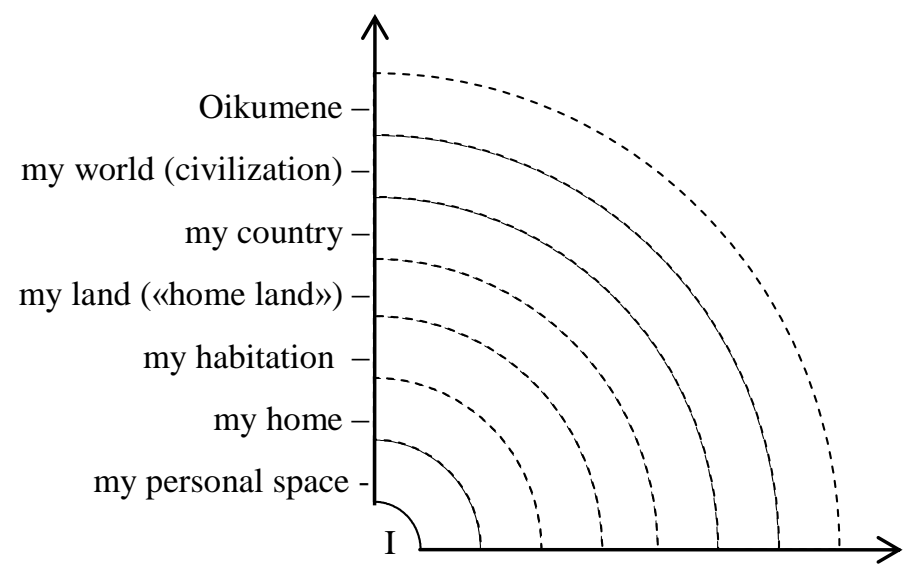

Fig. 1. «Security perimeter» organization

A system-forming core of «security perimeter», where a part of internal and most of external ties of this concept are closed, is home [3].

American scholars pass an opinion that «home» is not simply the actual, but the central concept of universal human being, having at the same time bright ethno-cultural specific character [8, p. 111].

A set of dominant features of home as archetypical image corresponds to its principal functions, the main of which is to define and mark the boundaries of a safe space in macro cosmos, to create one's own micro cosmos. Macrocosmos «security» implies air-tightness of home microcosmos. However, for human existence, the contacts with the external world are indispensable to life, therefore, «home» must have an opening to come in and out. An absolutely air-tight «home» is «wrong», since there is no exit outside: it might be a coffin, a grave [2, p. 23]. The presence of such opening - the rupture in monolithic protection of «security perimeter» - automatically implies vulnerability of the protected space.

The present paper attempts to consider the conception of «security perimeter» from the viewpoint of vulnerability to negative external impacts on the basis of the fragment of folkloric picture of the world «home», reconstructed before on the material of the English and Russian popular ballads [6].

The study has been based on the voluminous text material of popular ballads of England, Scotland and Russia with the help of numerous methods [5; 10] (see a detailed information about materials and the used research methods in: [6]).

In the texts of English and Scottish ballads, the semantic structure of home is blurred: it is the blending of the meanings of home as the locus of family and more general meaning of native land, a safe room of habitation of the characters of narration. Symbolically, the word home conveys the meaning «friend» in the mythological opposition «friend - foe» and, accordingly, carries semiotic load of a safe place of habituation. Therefore, the semantic opposites of the word home in the folkloric text of a ballad are the loci that are hostile towards the main character sea, green forest, wood, hill, churchyard, as the places of habituation of dark forces of evil or foes. House can be both «friend», the locus being native for the character, and «foe», the locus belonging to another family, sometimes being fraught with danger.

Door in ballads is the main border between «small» house (or its separate premises: bower, chamber) and the surrounding world and plays often the role of obstacle on the way of unexpected or unwelcome guests, protecting the house against forcible entry, therefore, important are the actions relating to shutting, locking the door. The door sometimes stands for the border locus between the world of the living and the dead. The popular tradition prohibits to leave the door ajar, as it makes the house the most vulnerable to intrusion of dark forces of evil and evil spirits, and this fact is fixed in the English ballad [10, v. 2, p. 281].

Window is a non-regulated entry-exit and, therefore, more dangerous than the door, as one can get into it against the will of the owners of the house. The mythological symbolism of the window, as well as of the door, relates to its borderline between «own» and «alien» world and the hazard of intrusion into the dwelling through the least protected place. Crossing the border of the window is a forbidden step in most cases, only ill-wishers can get inside the house against the masters' will. The important in the ballad are the actions connected with the necessity of protecting this locus, they are usually expressed by the constructions in passive voice and the participles in past tense.

Wall as the border of a «large» house is found mainly in combination with the epithet castle, forming, in certain cases, the composite castle-wall. This concept in the texts carries the main semiotic 
load of the border between «home», lived-in space of the house and outer space. Only the ghosts can cross the wall border.

Hall is a locus inside the house where many strange people are let in, therefore, it is saturated with the events and living actions in the English ballads (including murders which are committed here and cleared).

Bower is a smaller model of the house, has its boundaries, and methods of contact with the outside world (bower-door, bower-window, bower wall). The actions at the closed door (bower-door) repeat the actions at the gates and doors of the «large» and «small» house. Bower is carefully protected, forcible violation of its boundaries can lead to tragedy. Its semantics also reflects the idea of comfort and security of native home, to leave its boundaries voluntarily means to sacrifice comfort and personal safety.

Inside a chamber, as well as a bower, only the family members, servants and lovers are allowed. A Lover in the locus of the bedroom is «a friend» for the heroine, and «a foe» for all the other inhabitants of the house, so troubles can lie in wait for him.

Дом (House) symbolically realizes the opposition of the protected «own» space in relation to the «alien» hostile outer world, is a symbol of the native land. In the texts of the Russian ballads it confronts the loci of the outside world where the character can be surrounded by hazards, as well as the habitat of the hostile forces.

терем (Terem/Tower) opposes a foreign tent as a hazardous hostile locus. The space of терем (tower) includes жилье комнаты (living rooms), горницы (ирреr chambers/bowers), светлищы (front rooms), повальши (povalyshi). Killing the members of own family in the house or terem is a great $\sin$, so one tries to lure the victim into the mediator space of the yard or garden or within the boundaries of undeveloped space outside the «large» house. Terem, on the whole, is a symbol of prosperity and security.

The lexeme изба (izba) in the folkloric model of the world of ballads refers to a dwelling house of modest means as a whole or living quarters and has generally reduced or negative connotations in the folkloric model of the world of ballads, associating with poverty or hazard (the locus of evil spirits).

Двор (Courtyard) in the Slavic mythopoetic model is the mediator space between «own» and «alien» world, which is reflected in the texts of the Russian ballads. In the locus of the courtyard there are private constructions stable / stable yard, bathhouse, barn. The space of the yard as one's «own» developed world is opposed to the open field where the hazards of the outside world wait for the characters. At the same time, the yard is an open locus, which allows a large number of «strange» visitors to come in, not all of them are wanted to see in the house. The yard can be fraught with hazards, the characters on its territory are less protected than in the «small» house. In the locus of the yard there could be murders, deceit and betrayal of family members. Since the murder in the house was considered a great sin, one tries to lure the victim into the yard or in the bathhouse.

In the mythopoetic model of the world вopoma (gate) performs the function of a regulated entry and exit into the space of one's «own» developed world. In the Russian popular ballad the character is not always required to perform a ritual action related to letting in through the gate, often these actions are performed by the villains, as they are not wanted to be let in the house.

Окно (window) unlike дверь (the door) and вopoma (the gate) is an unregulated entry-exit and is therefore more semiotically loaded and associated with the hazards waiting for the characters from the outside world. The window in the house is opposed to the window in the bathhouse, which in the context of ballads appears as the locus near which the murders are committed.

Крыльио (роrсh) in the Russian folkloric model is a place outside of the «small» house, where the ways of movement out of the house into the outer space intersect, and vice versa. On the porch, the characters are more vulnerable than in the house, so there occur the demonstrative murders that are sinful to be committed in the house.

In the texts of the Russian ballads горница (upper chamber) acts as an opposite to the loci located outside the «large» house. Opposition горница (upper chamber) - чисто поле (open field), улииа (street) opposes the most secure locus home to the hazardous locus of the outside world, the opposition горниия (the upper rоот) - сырая земля/желтый песок/гробовая доска (damp earth / yellow sand / grave) contrasts the locus of the world of the living with the world of the dead. Горница, светлица, спальня и повальиши (иррег room, front room, bedroom and povalyshi) in the folkloric texts are synonymous as the most protected loci inside the house.

Двери (door) is an important boundary of the house, performing a protective function. Two doors between which there is сени (outer entrance hall) usually lead to a living zone of the house. An exterior door opens onto the porch. The main semiotic load of the door is related to its protective function: it is made of a hard material, it is usually closed, it is unlocked if necessary.

Door and gate in the Slavonic tradition were the objects and loci of special rites (in addition to knocking), associated with the symbols of the boundaries between one's «own» and «alien» space in 
the Christian tradition, so in the Russian ballads, one finds the descriptions of rituals of the characters before the door being not familiar to Western Christianity.

The bathhouse in the texts of ballads is a separate building in the territory of the «large» house. It is partially similar to the house in its construction, as evidenced by the presence of окошко, лавки, порог, печка (трубёшка) / the small window, the bench, the threshold, the stove (trubeshka). In the context of the ballad the bathhouse performs its main function of the room for washing. On the other hand, according to the popular believes the role of «unclean» place inhabited by demonic creatures is attributed to the bathhouse. In the texts of folk ballads, it is the bathhouse where the most violent crimes, murders of some family members occur. If one wants to hide the crime from other family members the bathroom is the most appropriate locus.

In the English and Russian folk models of the world, one of the most important loci of the house is the place of family hearth. This locus is the center of the house, its vital organizing principle, has at the same time the links with the outside world through the chimney or pipe, thus being a borderline locus. In the Russian folk ballads it is designated by the lexeme neчb, in English - fire / kitchen-fire.

As a result, the structure of folk models of the house in the English and Russian folk ballads reveals similarities and differences at the level of the mentioned lexemes [6]. The lexemes, indicating the boundaries of the house -window/окно, door/дверь, gate/ворота agree in the main components of the semantics. Partial coincidences are in the lexemes, denoting different loci in the territory of the house: bower, chamber, palour, room, hall, fire / горница, светлица, спаленка, повальиши, печь. In the English folk model there are no lexemes that correspond to the Russian words сенu, крыльио, двор, баня; in the Russian model, the lexemes denoting the concepts that correspond to the English kitchen, castlewall are not found.

In the English model of the world house appears as the closed space, having clear boundaries (castlewalls), in which a large role is played by the private loci (bower, chamber, room) and by the border of entry / exit door. Contact with the community is selective and occurs behind the «closed» door of the «large» or «small» house, often in the space of hall, as well as via visual and auditory contact through window. The space of the courtyard is an unmotivated semantic lacuna for the genre of the English ballads, at the same time, a functionally significant locus is stable, since it is a transition point of movement from the house into the outer space. House in the English folk ballad has also a lexically destined place for household servants (kitchen), which is also at the same time a hazardous locus of communication with the other world, as it borders with the outside world through the hearth (fire).

The Russian house, unlike the English one, is presented as an open type of communication that has no clear boundaries (the lexeme denoting the boundary of the house is absent in the Russian folk model). The Russian house is characterized by functionally important mediator space of the yard $(\partial в о р)$ (the lexeme denoting the space of the yard is absent in the English folk model) and, unlike the English ones, less important private loci that have no distinct boundaries.

Thus, the fact that in the mythological and folk pictures of the world the house is an open system leads to the supposition that at this level there are «gaps» in «security perimeter».

It should be also noted that the components of the macro system «security perimeter» displays the properties of self-similarity at different hierarchical levels (separate subsystems of the system «house» $\leftrightarrow$ system «house» $\leftrightarrow$ «security perimeter» as the whole), which allows to make an assumption about fractal character of its organization.

\section{References:}

1. Breus, I.V. The space of a house and antihouse in the works of J.K. Rowling. Almanac of modern science and education 2 (9), part II (2008): 28-29.

2. Maslova, V.A. Archetype of a boundary as a model of space perception. New paradigms and new solutions in modern linguistics 9 (2013): 22-25.

3. Morel Morel, D.A., Zubkova, V.K. About the means of representing the reflective concept «SECURITY PERIMETER» (comparative study case). Almanac of modern science and education 2 (9), part II (2008): 101-106.

4. Prokofiyeva, V.Yu. The category of space in the artistic interpretation: loci and topoi. Herald of OSU 11 (2005): 87-94. 1983.

5. Russian folk ballads. Moscow: Sovremennik,

6. Ryazanova, E.V. Building logical and conceptual models in the genre of English and Russian folkloric ballads. ISISS of RAS № 59664 (16.03.2006).

7. Hall, E.T. The hidden dimension. N.Y.: Anchor Books, 1990.

8. Jackson, N. Home in Russia: Cultural Values Embedded in Russian Homes. In Materials of NCA National Convention "Moving Forward / Looking Back", 111-123. Chicago, 2004.

9. Leroi-Gourhan, A. Le geste et la parole. P.: A. Michel, 1965. Vol. 2: La mémoire et les rythmes.

10. The English and Scottish Popular Ballads. N.Y.: Dover Publications, 1965. Vol. 1-5. 